\title{
Population dynamic of Big Eye Scad (Selar crumenophthalmus Bloch, 1793) in Kwandang Waters-Sulawesi Sea
}

\author{
Umi Chodrijah ${ }^{1 *}$, Ria Faizah $^{2}$, and Tirtadanu ${ }^{1}$ \\ ${ }^{1}$ Researcher at Research Institute for Marine Fisheries, Bogor, Indonesia \\ ${ }^{2}$ Researcher at Research at Center for Fisheries, Jakarta, Indonesia
}

\begin{abstract}
Big eye scad (Selar crumenophthalmus) is one of important small pelagic fish which is exploited in Kwandang waters-Sulawesi Sea. The exploitation of this species has been increasing every year. This research was carried out to study the growth, mortality and exploitation of bigeye scad in the Kwandang waters during January-November 2016. The von Bertalanffy growth equation was derived as $\mathrm{Lt}=25.95\left(1-\mathrm{e}^{1,01(\mathrm{tt}-}\right.$ ${ }^{0.16374)}$ ) with length between $14.9-26.4 \mathrm{~cm}$ FL (average length $18,64 \mathrm{~cm}$ ). The size at first capture (Lc) was estimated as $18.69 \mathrm{~cm}$. The total, natural and fishing mortality rates were assessed as $4.28,1.90$ and 2.38 year-1, respectively. The exploitation rate (E) of 0.56 per year indicates that the degree of harvesting leads to a more capture condition.. The management that must be applied is to reduce fishing efforts to $12 \%$ of the current situation and to consider temporarily closing fishing activities (closing season).
\end{abstract}

\section{Introduction}

Sulawesi Sea is one of important habitats for fishing ground of fisheries resources especially small pelagic fish. Sulawesi sea is located in the western part of Pacific Ocean has important rule as fisheries management area, it is because of many fisheries activities both small scale and industry scale in this area. The main base for small and large pelagic fisheries in Sulawesi Sea is Kwandang waters, Gorontalo province. Some pelagic species in the Kwandang waters are Indian scad (Decapterus spp which is consist of 3 species), Indian mackerel (Rastrelliger kanagurta), bigeye scad (Selar crumenophthalmus), and anchovy (Stolephorus spp) consist of two species; sardine (Ambligaster sirm and Sardinella spp.).

The Kwandang fishers caught the small pelagic fish by purse seine/pajeko, gillnet, floating cage, hook and danish seine. The small pelagic fisheries contributed to total production was about 59, 40\% from 2011 to 2015 . The catch declined $46.57 \%$ during 2012 to 2014. One of small pelagic fish that have an important value and highly exploitation is bigeye scad (Selar crumenophthalmus). During six years, bigeye scad contributed at $8.11 \%$

\footnotetext{
${ }^{*}$ Corresponding author: umi_chodriyah@yahoo.co.id
} 
to small pelagic fish in the Kwandang waters and the catch increased every year. The highly exploitation this fish will disturb fisheries sustainability.

The studies about bigeye scad in Indonesia waters have already conducted by [1] in Kwandang, Semarang waters in 2016 [2], in Banda Sea [3], in North Moluccas [4], and Sulawesi Sea [5], [6] and [7] in Java Sea. The objective of this study were defined to population dynamic of bigeye scad (Selar crumenophthalmus) caught in Sulawesi Sea and landed in the Fishing Port Kwandang, Gorontalo. The benefit of this study provides information about exploitation rate of bigeye scad so that it could be used as a biological reference for optimum and sustainable exploitation.

\section{Method}

\subsection{Time and Location}

The study was conducted in the Fishing Port Kwandang, Gorontalo from January to November 2016.

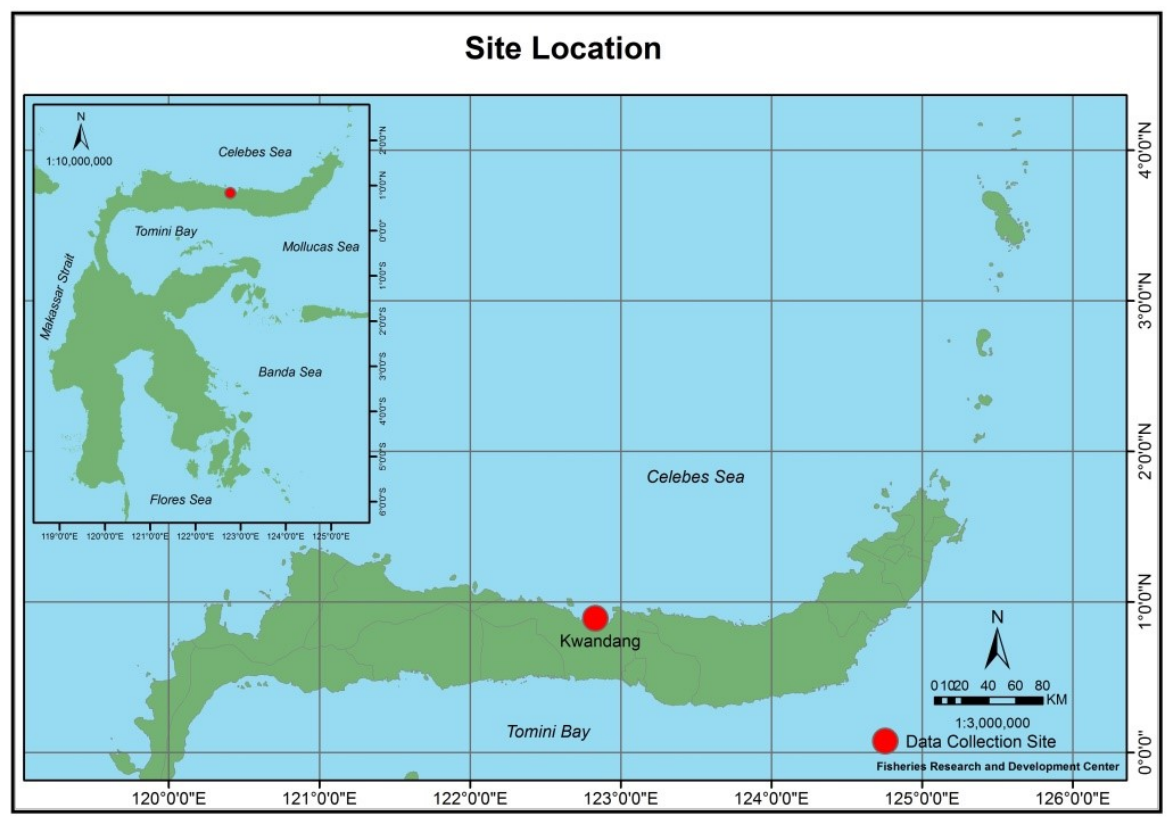

Fig. 1. Map showing of the study in Kwandang-North Gorontalo

\subsection{Sampling procedure}

The fish length measurements were taken during January to November 2016. Samples of bigeye scad (Selar crumenophthalmus) were taken by random then each sample was measured fork length (FL) using a special measuring paper with a precision of $0.5 \mathrm{~cm}$. 


\subsection{Analisis data}

\subsubsection{Growth parameters}

Length frequency was grouped then analyzed using software program FiSAT (FAOICLARM Stock Assessment Tools) [8]. The growth parameters such as The von Bertalanffy's Growth Function (VBGF) as length of infinity $\left(\mathrm{L}_{\infty}\right)$ and growth coefficient (K) were estimated by using ELEFAN-I (Electronic Length Frequency Analysis) program in FiSAT. Age at length $0\left(\mathrm{t}_{0}\right)$ was estimated using [9], as:

$$
\log 10(-t 0)=-0.3922-0.2752 \times \log 10\left(L_{\infty}\right)-1.038 \times \log 10(K)
$$

where $\mathrm{L} \infty$ in $\mathrm{cm}$ and $\mathrm{K}$ in year.

The length reached by species at a certain age was estimated by using the von Bertalanffy growth equation, which is:

$$
L_{t}=L_{\infty}\left[1-\exp \left\{-K \times\left(t-t_{0}\right)\right\}\right]
$$

Fish growth rates can also be obtained based on the growth equation of Von Bertalanfy [10] as follows:

$$
\Delta L / \Delta t=K *\left(L_{\infty}-L(t)\right)
$$

Where :

$\mathrm{L}(\mathrm{t})=$ fish length when age at $\mathrm{t}(\mathrm{cm})$

$\mathrm{L}_{\infty}=$ asymptotic length of fish $(\mathrm{cm})$

$\mathrm{K}=$ growth coefficient of von Bertalanffy

$\mathrm{t}_{\mathrm{o}}=$ fish at age theories when length at $0 \mathrm{~cm}$

\subsubsection{Mortalitaty}

Total mortality $(\mathrm{Z})$ analysed by catch curve approaches and it converted to length (Length Converted Catch Curve Analysis) in the FiSAT II software [11]. The approach was taken by data input of growth parameters ( $\mathrm{L}_{\infty}$ and K) was following Beverton \& Holt (1986) equation in [11] as :

$$
Z=\frac{K\left(L_{\infty}-L^{\prime \prime}\right)}{\left(L^{\prime \prime}-L^{\prime}\right)}
$$

Where is:

$\mathrm{Z}=$ total mortality rate (per year)

$\mathrm{L}_{\infty}=$ asymptotic length of fish $(\mathrm{cm})$

$\mathrm{K}=$ growth coefficient

$\mathrm{L}^{\prime \prime}=$ average length of fish catch $(\mathrm{cm})$

$\mathrm{L}^{\prime}=$ lower limit of the highest catch class length interval $(\mathrm{cm})$

For natural mortality coefficient (M) was using empirical [12] equation as follow:

$\log (M)=-0,0066-0,279 \log (L \infty)+0,6543 \log (K)+0,4634 \log (T)$

Where is:

$\mathrm{M}=$ natural mortality rate

$\mathrm{K}=$ growth coefficient

$\mathrm{L}^{\prime \prime}=$ average length of fish catch $(\mathrm{cm})$

$\mathrm{T}=$ temperature average of waters 
Fishing mortality (F) was taken from reduction of total mortality to natural mortality as $\mathrm{F}=\mathrm{Z}-\mathrm{M}$.

\section{Results and Discussion}

\subsection{Length distribution}

The length distribution of bigeye scad (Selar crumenophthalmus) was presented in Figure 2. From the analysis of 3820 fish samples, the length of the bigeye scad ranged form 12 to $25 \mathrm{~cm} \mathrm{FL}$, with an average of $18.64 \mathrm{~cm}$ FL and the highest mode at 18,5 cmFL. This size was bigger than the result before in the same areas were 13-21 cm FL [1]. This size was also bigger than the size from Bangaa Faru Maldives were $7.7-24.5 \mathrm{~cm}$ (average 16.85 $\mathrm{cm}$ ) [13] from Thailand bay between $6.5-26.5 \mathrm{~cm}$ (average $15 \mathrm{~cm}$ ) [14] and from Pulau Reunion, Southwest part of Indian Ocean was 6,5 -25 cm [15].

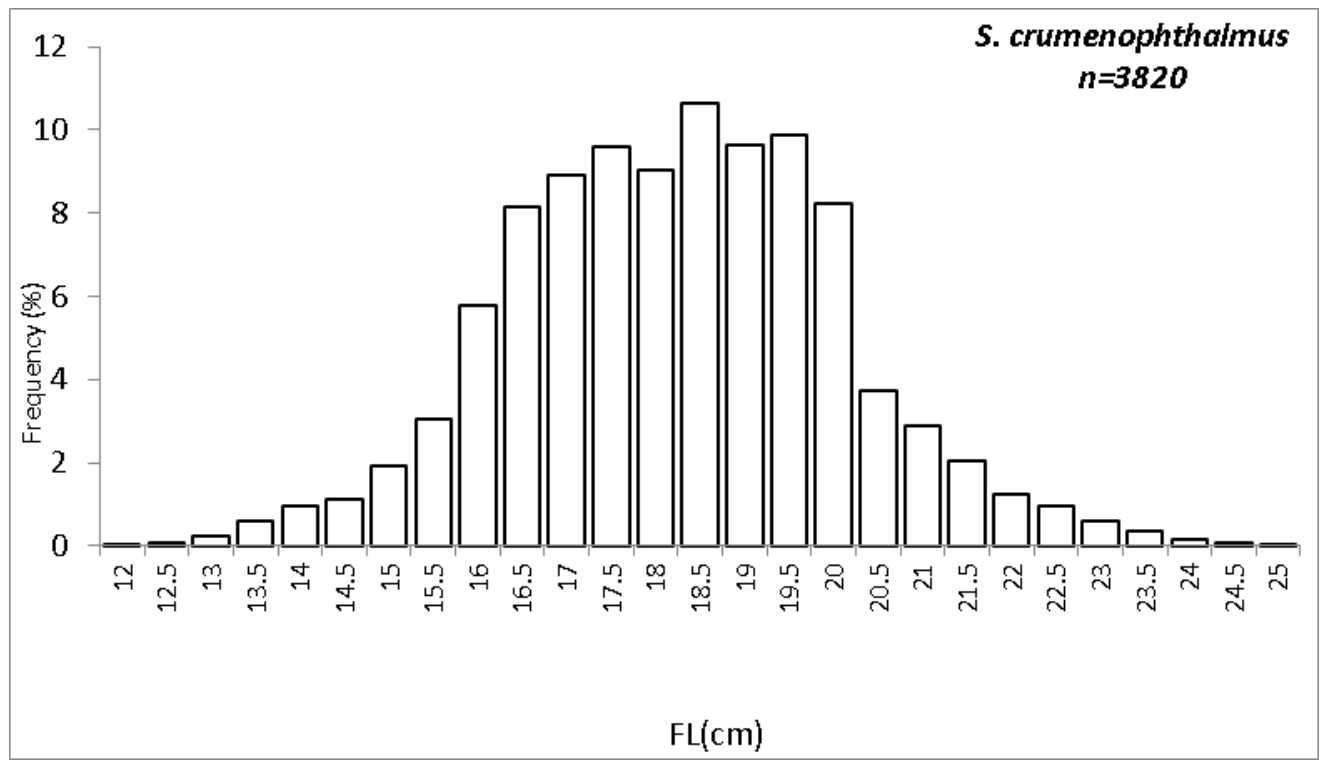

Fig. 2. Length frequency distribution of bigeye scad (Selar crumenophthalmus) in Kwandang waters, 2016

\subsection{Length at first Capture (L-50)}

Based on the analysis, length at first capture (Lc) of bigeye scad caught by handline was $18.69 \mathrm{~cm}$ (Figure 3) Based on the previous research [16] stated that length at first maturity from the same water is $17.69 \mathrm{~cm}$. The average estimate length at first capture (Lc) larger than the length at fisrt maturity $(\mathrm{Lc}>\mathrm{Lm} ; 18.69 \mathrm{~cm}>17.69 \mathrm{~cm})$ so that the recruitment pattern can still be carried out. 


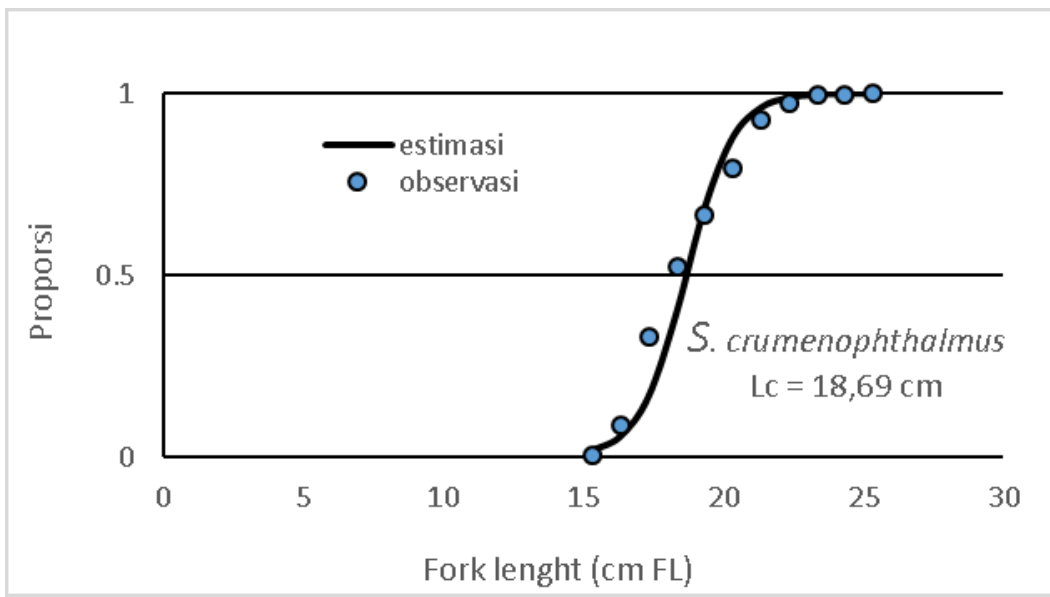

Fig. 3. Length of first capture (L-50) of bigeye scad (Selar crumenophthalmus) in Kwandang waters, 2016

\subsection{Growth Parameters}

Based on the analysis, the infinitive length of bigeye scad $\left(\mathrm{L}_{\infty}\right)=25.95 \mathrm{~cm}$ and growth coefficient $(\mathrm{K})=1.01$ per year. Von Bertalanffy Growth Graph of bigeye scad in Kwandang waters is presented in Figure 5.

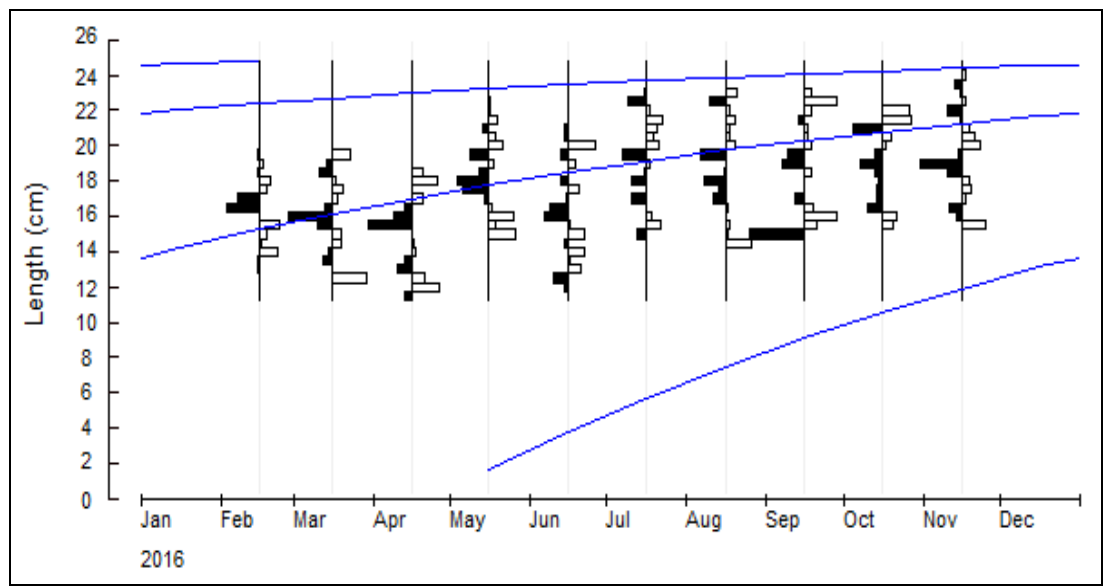

Fig. 4. Von Bertalanffy curve of bigeye scad (Selar crumenophthalmus) in Kwandang waters, 2016

The length of infinity in this study was $25.95 \mathrm{cmFL}$ with a $\mathrm{K}$ value of 1.01 per year. Several studies of bigeye scad in the Java Sea conducted by [17] [18] and [5] obtained L $\infty$ and $\mathrm{K}$ values, respectively, $\mathrm{L} \infty=26.90 \mathrm{~cm}$ FL with $\mathrm{k}=1,350 \mathrm{~cm}, \mathrm{~L} \infty=25.90 \mathrm{cmTL}$ with $\mathrm{k}$ $=1,250$ and $\mathrm{L} \infty=26.10 \mathrm{cmTL}$ with $\mathrm{k}=1,100$. The results of the study of [19], in the waters of Mumbai obtained $\mathrm{L}_{\infty}=31 \mathrm{~cm}$ with $\mathrm{K}=1.4$. The results of other studies that similar with this study were conducted by [20] in Bangaa Faru waters with $\mathrm{L}_{\infty}=26.50 \mathrm{~cm}$ $\mathrm{FL}, \mathrm{k}=0.93$ and in the Gumairas Strait of the Philippines, $\mathrm{L} \infty=25.4$ with $\mathrm{K}=1.00$ [21]. Based on several research results in several different waters, it can be seen that bigeye scad has $K \geq 1$ with a long life was 1-3.5 years, which means the bigeye scad growth was relative fast because according to [22], fish with a $\mathrm{K}$ value less than one shows that this fish has slow growth. The difference in growth parameter values from the von Bertalanffy 
equation is influenced by the number of samples obtained, and is determined by environmental conditions such as latitude, temperature, salinity [23,24]. In addition, fisheries activities and pressures also affect population dynamics. If the pressure is high, overfishing can be occurred, and the adult age group can disappear [25,26].

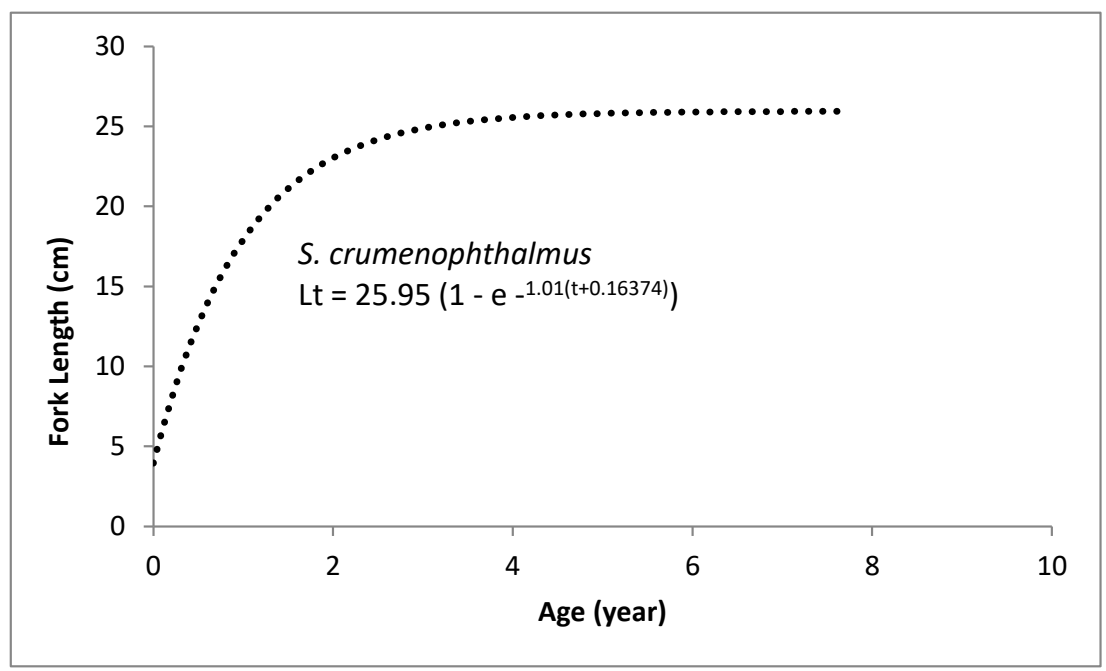

Fig. 5. Curve of age-length relationship of bigeye scad (Selar crumenophthalmus) in Kwandang waters, 2016

\section{Total mortality rate (Z), Natural (M), Fishing (F) and Exploitation rate (E)}

The total mortality $(Z)$ of bigeye scad fish in the Sulawesi Sea was 4.28 per year. The average annual temperature in the Sulawesi Sea was $29^{\circ} \mathrm{C}$, the natural mortality (M) of bigeye scad was 1.90 per year. Fishing mortality (F) was 2.38 per year with exploitation rate (E) was 0.56 per year. Curve catch in Sulawesi Sea waters is showed in Figure 6.

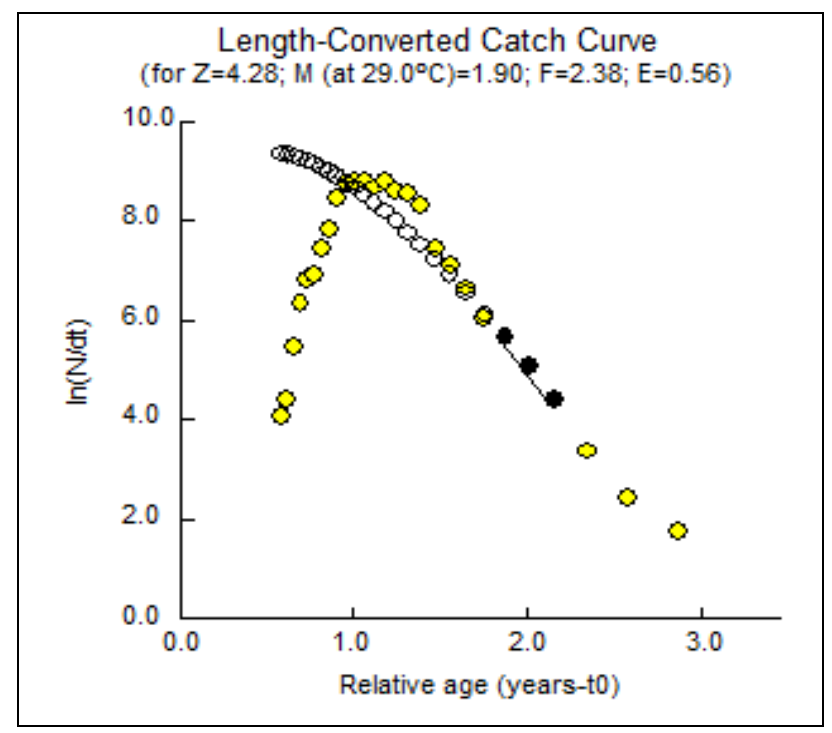

Fig. 6. Curve of catch by length of bigeye scad (Selar crumenophthalmus) in Kwandang waters, 2016 
The results of previous studies conducted by [1] in the same water, the natural mortality rate was 1.28 and the fishing mortality rate was 1.3 per year, almost balanced that can be considered as an optimal fishing mortality. Meanwhile in this research, the fishing mortality is greater than the natural mortality rate with an exploitation rate $(\mathrm{E})$ of 0.56 . Based on the exploitation level, it could be seen that the bigeye scad stocks during four years (20122016) in the Kwandang waters can be considered as optimal category because according to Gulland (1971) in [10], the stock was optimal exploitation if the fishing mortality rate (F) is equal to natural mortality rate $(\mathrm{M})$ or exploitation rate $(\mathrm{E})$ is 0.5 . The mortality parameters obtained in this study approached the results obtained by [19] in Mumbai waters namely $Z$ $=4.62 ; \mathrm{M}=2.21 ; \mathrm{F}=2.41$ and the exploitation rate $\mathrm{E}=0.52$. as well as the results of a study from $[20]$ which obtained a value of $Z=4.01 ; \mathrm{M}=2.23 ; \mathrm{F}=1.78$ with $\mathrm{E}=0.56$.

\section{Conclusion}

The average length at first capture $(\mathrm{Lc})$ is bigger than the length at first maturity $(\mathrm{Lm})$ so that recruitmen pattern can still be carried out. The exploitation rate (E) of 0.56 per year indicates that the degree of harvesting leads to a more capture condition. The management that must be applied is to reduce fishing efforts to $12 \%$ of the current situation and to consider temporarily closing fishing activities (closing season).

This paper is contribution from research activities "Characteristics of fisheries, habitat of fish resources and potential production of fishery resources at FMA 716 (Celebes Sea)" at the Research Institue for Marine Fisheries, Jakarta, The author thanked officers of the enumerator in Kwandang Fishing Port, who has been assisting in data collection during the study.

\section{References}

1. R. Faizah, L. Sadiyah, L. T. Hariati, BAWAL 6(2), 111-117 (2014)

2. A.Siwat, Ambariyanto,I. Widowati, AACL Bioflux 9, 4 (2016)

3. A Zamroni,, Suwarso, BAWAL 3(5), 337-344 (2011)

4. A.R Syam, Prosisding Seminar Nasional Ikan IV (Jatiluhur, 2006)

5. Suwarso, A. Kuswoyo, M. Fauzi, Bunga Rampai Status Pemanfaatan sumber Daya Ikan di perairan Laut Jawa dan Laut Sulawesi (BPPL, 2013)

6. A. Dwiponggo, T. Hariati, S B. Atmadja, MLD. Palomares, D. Pauly, ICLARM Tech. Rep. 17, 91 (1986)

7. B. Sadhotomo, SB. Atmadja, J. Pen. Perikanan Laut 33, 53-60 (1985)

8. Jr. F. C.Gayanilo., P. Sparre, D. Pauly, FAO-ICLARM Stock Assesment Tools (FISAT) (FAO United Nations, 1996)

9. D.Pauly. J. Cons. Int. Explor. Mer. 39, 175-192 (1980)

10. P. Sparre, S.C. Venema. Buku 1 (Manual. FAO fish. Tech, 1999)

11. Jr.F.C. Gayanilo, D. Pauly, FAO Computerized Information Series (Fisheries) 8, 2 (1997)

12. D.Pauly, Fish population dynamics in tropical waters: A manual for use with programmable calculators (ICLARM. Stud. Rev. 8,1984)

13. N. Fazhly, S. Adeeb, A.S.R M.Sah, Trop. Life Sci. Res. 28(2), 127-141 (2017)

14. K. Phuttharaksa, N. Nasuchon, T. Kongchai, J. Pinputtasin. Technical Paper no. 16/2008 (Bangkok, MFRDB, DOF, 2008)

15. D. Roos, O. Roux F. Conand, SCIENTIA MARINA 71, 137-144 (2007)

16. Chodrijah, U., Faizah, R. BAWAL 10(3), 169-177 
17. B. Sadhotomo, SB Atmadja, J. Pen. Perikanan Laut 33, 53-60 (1985)

18. Dwiponggo , T. Hariati, SB Atmadja, MLD. Palomares, D. Pauly. ICLARM Tech. Rep. 17, 91 (1986)

19. D. Panda,A.K. Jaiswar, SD., Sarkar, SK. Chakraborty. J. Mar. Biol. Assoc. UK. 96, 1411-1416 (2016)

20. S. Adeeb, N. Fadzly, ASRM. Sah, J. Mar. Biol. Oceanogr. 3, 3 (2014)

21. JE.Padilla, Managing tropical multispecies fisheries with multiple objectives ( $\mathrm{PhD}$ thesis, Simon Fraser University, Canada, 1991)

22. J.A. Gulland, Manual of Basic Method. FAO/Wiley Series on Food and Agriculture (Rome, 241, 1983)

23. E. Ford, J. Mar. Biol. Assoc. UK 19, 305-384 (1933)

24. L.A.Walford,The Biological Bulletin 90, 141-147 (1946)

25. N.RA Ortega, E. Espino-Barr, M Gallardo-Cabello, A. Garcia-Boa, M. Puente-Gómez, Rev.Biol.Mar .Oceanogr. 47, 273-281 (2012)

26. G.M.Cabello, E. Espino-Barr, A. Garcia-Boa, EG. Cabral-Solís, M. Puente-Gómez, Intl. J.Zool.Res. 2, 34-47 (2006) 